\title{
Ecological applications of Pseudomonas as a biopesticide to control two-spotted mite Tetranychus urticae: chitinase and HCN production
}

\author{
Redouan Qessaoui ${ }^{1,2}$, Rachid Bouharroud ${ }^{2 *}$, Abderrahim Amarraque ${ }^{2}$, Abdelhadi Ajerrar ${ }^{1,2}$, \\ El Hassan Mayad ${ }^{3}$, Bouchra Chebli ${ }^{1}$, Mokhtara Dadi ${ }^{2}$, Rachid Elaini ${ }^{4}$, Fayssal El Filali ${ }^{5}$, \\ Alan Stuart Walters ${ }^{6}$ \\ ${ }^{1}$ Laboratory of Environmental Engineering and Biotechnology, National School of Applied Sciences, Agadir, Morocco \\ ${ }^{2}$ Research Unit of Integrated Crop Production, Centre Regional de la Recherche Agronomiqued'Agadir (INRA), Morocco \\ ${ }^{3}$ Laboratory of Plant Biotechnology, Faculty of Sciences, Ibn Zohr University, Agadir, Morocco \\ ${ }^{4}$ Agronomic and Veterinary Institute Hassan II, Agadir, Morocco \\ ${ }^{5}$ Laboratory of Bacteriology, Specialized Center of Valorisation and Technology of Sea Production, INRH, Agadir, Morocco \\ ${ }^{6}$ Department of Plant, Soil, and Agricultural Systems, Southern Illinois University, Carbondale, IL USA
}

Vol. 57, No. 4: 409-416, 2017

DOI: 10.1515/jppr-2017-0055

Received: August 18, 2017

Accepted: November 20, 2017

*Corresponding address: bouharroud@yahoo.fr

\begin{abstract}
The two-spotted spider mite (Tetranychus urticae Koch) is an important pest of many horticultural crops. A study was conducted to evaluate the effect of three fluorescent Pseudomonas isolates obtained from rhizospheric soil of tomato (Solanum lycopersicon) in Agadir, Morocco: Q110B, Q036B and Q172B, as potential biological control agents for T. urticae. Both acaricide and repellent activities were assessed on homogenous adult mites. The acaricidal activity test evaluated five concentrations of bacterial suspensions: 0 (control), $10^{2}, 10^{4}, 10^{6}, 10^{8}$, and $10^{10} \mathrm{cfu} \cdot \mathrm{ml}^{-1}$, while only the $10^{10} \mathrm{cfu} \cdot \mathrm{ml}^{-1}$ concentration of each bacterium was used for the repellent bioassay. The mortality rate and repellentindex were recorded 24, 48 and $72 \mathrm{~h}$ after application. Results indicated that the survival rate of $T$. urticae was reduced $(\mathrm{p} \leq 0.01)$ by all three bacterial isolates compared to control. Within the $24-72 \mathrm{~h}$ time period the mortality rates ranged from 8 to $87 \%, 16$ to $99 \%$, and 13 to $89 \%$, for Q110B, Q036B and Q172B isolates, respectively. The isolate $\mathrm{Q} 036 \mathrm{~B}\left(\mathrm{LC}_{50}=0.598 \mathrm{cfu} \cdot \mathrm{ml}^{-1}\right)$ provided higher mortality rates than Q172B and Q110B with $\mathrm{LC}_{50}$ values of 90,846 and $169,585 \mathrm{cfu} \cdot \mathrm{ml}^{-1}$, respectively. Repellent activity was also the highest with Pseudomonas Q036B having a 71\% repellence index at $48 \mathrm{~h}$ after application. Regarding the mechanism of action, all three isolates produced hydrogen cyanide, and exhibited protease and cellulose activities, although only Q036B and Q172B had potential chitinase action. Identification analysis showed that the isolates were either Pseudomonas putida (Q172B) or P. fluorescens (Q110B and Q036B). Our results indicate that the P. fluorescens isolate Q036B is a promising candidate for biological control of $T$. urticae, and has potential to contribute to an integrated pest management program to control this important pest. Then the fruits produced will be qualified as safe for consumers and the environment. The present work was customized to give support for policy decision makers as an agroecological potential meeting needs of industries and ecological balance.
\end{abstract}

Key words: biological control, biopesticide, chitinase, ecology, Pseudomonas, Tetranychus urticae 


\section{Introduction}

The two-spotted spider mite, Tetranychus urticae Koch (Acari: Tetranychidae), is a polyphagous pest that is distributed worldwide. This pest can cause significant yield losses in many agricultural crops, including fruits, cotton, vegetables, and ornamentals (Neethu et al. 2015). Direct plant damage is due to feeding punctures. This pest pierces the epidermis and feeds on the contents of mesophyll cells that results in chlorosis, due to a decrease in total chlorophyll content and an eventual loss of photosynthetic capacity. Under heavy two-spotted mite infestations, the plant will often times die (Park and Lee 2002). Spider mites can infest more than 1,000 different plant species in more than 100 plant families (van Leeuwen et al. 2010). Adaptive strategies of spider mites are based on high fecundity of females and a female-biased offspring sex ratio, which can lead to a rapid population increase (Carey and Bradley 1982). In conventional chemical control management of $T$. urticae, broad spectrum acaricides are often sprayed to reduce population levels. However, they can also eliminate natural enemies, including predatory mites. Moreover, acaricides can cause the development of pesticide-resistant mite populations (Attia et al. 2012).

A definition of biological control is: "the use of living organisms to reduce damage caused by pests and diseases to tolerable levels". Biological control methods have become more and more necessary (Fiedler 2012) since some pesticides are not allowed and the use of others is restricted due to very low residue limits. Indeed, the use of biological control agents is the most cost effective method to control pests (van Lenteren 2012). However, the net benefits derived from biological control are difficult to quantify with any degree of accuracy except in a closed and totally controlled system (glasshouse).

Biological control agents such as parasites, predators, bacteria or fungi can be used as alternative strategies for management (Arzanlou et al. 2016; Hamza et al. 2016). Bacterial organisms, such as Xenorhabdus spp., Yersinia entomophaga, Pseudomonas entomophila, Burkholderia spp., Chromobacterium spp., Streptomyces spp., Bacillus spp. and Saccharopolyspora spp., have all recently gained commercial interest for production of numerous metabolites that act as potent insecticides (Ruiu 2015). Chitinase enzymes that are able to degrade chitin present in the cell walls of fungi and insect exoskeletons are thought to be one of the important metabolites produced by these bacteria. Thus, several pathogenic bacterial organisms have potential as biological control agents for various fungal and insect pests. Therefore, they can be used as an alternative to chemical pesticides (Rathore and Gupta 2015).
Fluorescent Pseudomonas species have also been shown to be effective in the biological control of the two-spotted spider mite pest. Aksoy et al. (2008) indicated that $P$. putida, isolated from tomato soils in Turkey, provided high mortality rates to two-spotted spider mites. Furthermore, P. fluorescens produces bacterial chitinases which are effective in controlling the mites by hydrolyzing their chitinous exoskeleton (Roobakkumar et al. 2011). Therefore, the objective of this study was to evaluate the efficacy of fluorescent Pseudomonas isolates, from tomato rhizospheric soil obtained in Agadir, Morocco, as a biocontrol agent against T. urticae.

\section{Materials and Methods}

All experiments were conducted in a growth room at $25 \pm 1^{\circ} \mathrm{C}, 16: 8 \mathrm{~h}(\mathrm{~L}: \mathrm{D})$ photoperiod, and $55 \%$ relative humidity (RH), at the Laboratory of Integrated Crop Production Unit, National Institute of Agronomic Research (INRA), Agadir, Morocco.

\section{Isolation and characterization}

Pseudomonas bacteria were isolated from rhizospheric soil of tomato plants at the experimental farm of INRA, Agadir, Morocco. For isolation King's B medium (King et al. 1954) was used and fluorescent Pseudomonas were selected under UV light $(360 \mathrm{~nm})$. The selected bacteria were characterized according to their response to the following biochemical characteristics: Gram-positive/negative, motility, oxidase, catalase, arginine-dihydrolase and Leven production (Falkow 1958), glucose fermentation (Hugh and Leifson 1953), nitrate reduction, gelatin hydrolysis, gelatin liquefaction, and carbon source utilization (Bossis et al. 2000). Growth conditions such as temperature, $\mathrm{pH}$ and salt tolerance were also evaluated (Bossis et al. 2000). Fluorescent Pseudomonas isolates were identified using API 20NE test (BioMerieux, SA, France) (Sarma et al. 2012). Concentrations used in this study were obtained by adding an aliquot of each bacterial isolate to $100 \mathrm{ml}$ of nutrient broth amended with $0.1 \%$ Tween 20 and incubated in an orbital shaker incubator at $28^{\circ} \mathrm{C}$ and $150 \mathrm{rpm}$ for $24 \mathrm{~h}$. After incubation, centrifugation was performed at 10,000 rpm. Bacteria cells were adjusted in $640 \mathrm{~nm}$ using a spectrophotometer (Optizen 3220UV/VIS double beam, Mecasys, South Korea) at five concentrations $\left(10^{2}, 10^{4}, 10^{6}, 10^{8}\right.$ and $10^{10} \mathrm{cfu} \cdot \mathrm{ml}^{-1}$ ) (Zhang et al. 2014). Sterile distilled water was used for control. 


\section{Acaricidal activity}

Three fluorescent Pseudmonas bacterial strains Q110B, Q036B and Q172B were assessed for their ability to cause mortality to homogeneous age adults of T. urticae on tomato (Solanum lycopersicon) leaves. The experiment was set up as a 3 (bacterial isolates) $\times$ $\times 6$ (concentrations) $\times 3$ (time intervals) factorial in a randomized complete block design with four replications and three runs. The population of T. urticae used was maintained for more than 30 generations on tomato crops. Fresh leaves of 'Prystila' tomato (Gautier seeds company, France) were collected from unsprayed plants growing in a greenhouse (INRA experimental farm, Agadir, Morocco). The leaves were first washed with tap water and rewashed with sterile distilled water, and then dried under a laminar flow hood.

The effect of bacterial isolates on T. urticae adults was studied under laboratory conditions using a leafdip bioassay (Bouharroud et al. 2007). A leaf cage was prepared from Petri dishes $(9 \mathrm{~cm})$ containing Whatman paper soaked in sterile distilled water. A $1.5 \mathrm{~cm}$ diam. hole was made in the lid of Petri dishes and covered with muslin. Tomato leaflets were dipped in each isolate and concentration combinations for $20 \mathrm{~s}$. The treated leaflets were dried under a laminar hood then transferred to leaf cages. The control leaflets were dipped only in sterile distilled water. Fifteen T. urticae adults(male to female sex ratio: $1-1.1$ ) were then transferred to treated leaflets. Four replicates for each leaf cage and concentration were used. The cages were incubated at $24 \pm 2^{\circ} \mathrm{C}$ with a photoperiod of $16: 8 \mathrm{~h}$ (L : D), and T. urticae mortality rate was assessed 24,48 and $72 \mathrm{~h}$ after treatment. The bioassay was replicated three times. Two-spotted mite mortality rates were corrected using Abbott's formula (Abbott 1925):

$$
\text { CrrM [\%] }=\frac{\mathrm{DMN}-\mathrm{DMNC}}{\mathrm{MTN}-\mathrm{DMNC}} \times 100,
$$

where: CrrM - corrected mortality, DMN - dead mite number, DMNC - number of dead mites in control, MTN - total mite number.

\section{Repellent activity}

This experiment measured the repellent activity of the fluorescent Pseudomonas isolates on T. urticae adults. The $10^{10} \mathrm{cfu} \cdot \mathrm{ml}^{-1}$ concentration (which provided the highest acaricidal activity in the previous experiment) was used. The modified choice test described by Pascual-Villalobos and Robledo (1998) was used to determine T. urticae repellent activity. This procedure used two boxes (that contained either control or treated leaves) connected with a $10 \mathrm{~cm}$ long translucent hose $(1 \mathrm{~cm}$ diam.) having a hole in the center that allowed the introduction of two-spotted spider

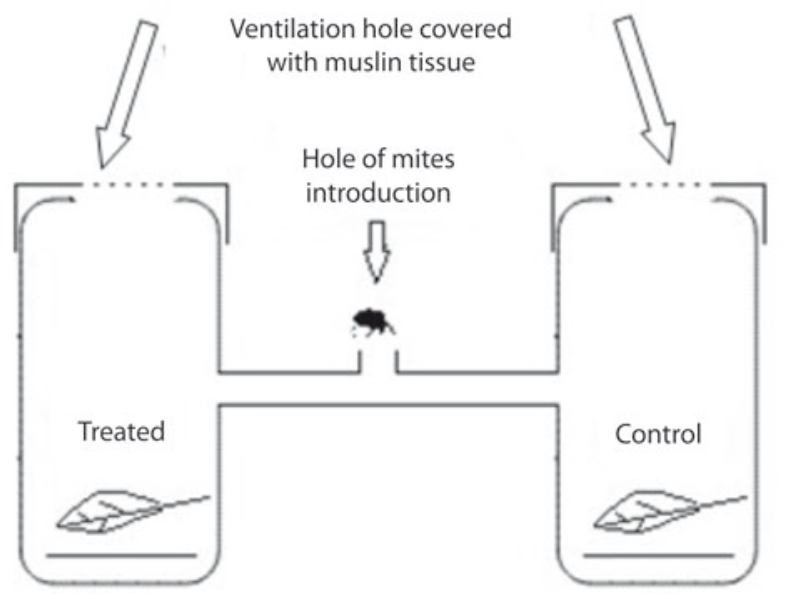

Fig. 1. Experimental apparatus adopted using tomato leaflets treated with either fluorescent Pseudomonas isolates or distilled water (control) for two-spotted mite repellent test

mites (Fig. 1). Leaflets were immersed for $20 \mathrm{~s}$ in either a bacterial suspension $\left(10^{10} \mathrm{cfu} \cdot \mathrm{ml}^{-1}\right)$ or distilled sterile water, placed under alaminar flow hood until dry, and then placed in the corresponding box in the repellent apparatus. Twelve T. urticae adults (male to female sex ratio: 1 to 1.1 ) were then transferred gently through the hole pierced in the middle of the linked-hose and then sealed. This system allowed mites to move freely to the control or treated box.

The experiment was set upasa 3 (bacterial isolates) $\times$ $\times 2$ (concentrations) $\times 3$ (time intervals) factorial in a randomized complete block design with four replications and three runs. Experiments were conducted in a growth room at $25 \pm 1^{\circ} \mathrm{C}, 16: 8 \mathrm{~h}(\mathrm{~L}: \mathrm{D})$ photoperiod, and $55 \% \mathrm{RH}$. The migration of mites to one of the two linked boxes was determined at 24, 48 and $72 \mathrm{~h}$ after release. A repellency index was calculated using the formula of Pascual-Villalobos and Robledo (1998):

$$
\mathrm{RI}=\frac{\mathrm{C}-\mathrm{T}}{\mathrm{C}+\mathrm{T}} \times 100,
$$

where: RI - repellency index, C - number of T. urticae adults in the control box, $\mathrm{T}$ - number of T. urticae adults in the treated box.

\section{Mechanism of action of Pseudomonas strains}

\section{Chitinase production}

The ability of an isolate to produce chitinase was determined as described by Cattelan et al. (1999) in medium composed of $\left(\mathrm{g} \cdot \mathrm{l}^{-1}\right)$ : colloidal chitin prepared from crab shells (0.8); $\mathrm{NH}_{4} \mathrm{NO}_{3}$ (0.78); $\mathrm{K}_{2} \mathrm{HPO}_{4}$ (0.20); $\mathrm{MgSO}_{4} \cdot 7 \mathrm{H}_{2} \mathrm{O}(0.20) ; \mathrm{CaCl}_{2}$ (0.06); $\mathrm{NaCl}(0.10) ; \mathrm{Na}_{2} \mathrm{MoO}_{4} \cdot 2 \mathrm{H}_{2} \mathrm{O}$ (0.002); $\mathrm{ZnSO}_{4} \cdot 7 \mathrm{H}_{2} \mathrm{O}$ (0.00024); $\mathrm{CuSO}_{4} \cdot 5 \mathrm{H}_{2} \mathrm{O}$ (0.00004); $\mathrm{CoSO}_{4} \cdot 7 \mathrm{H}_{2} \mathrm{O}$ 
(0.010); $\mathrm{MnSO}_{4} \cdot 4 \mathrm{H}_{2} \mathrm{O}$ (0.003); $\mathrm{Na}_{2}$ FeEDTA (0.028); $\mathrm{H}_{3} \mathrm{BO}_{3}$ (0.005); and, agar 15 (Sigma-Aldrich Chemical Co., USA). Magnesium sulfate and $\mathrm{CaCl}_{2}$ were autoclaved separately and then added later to the medium after autoclaving. Biotin $\left(5 \mu \mathrm{g} \cdot \mathrm{l}^{-1}\right)$ and $\rho$-aminobenzoic acid $\left(10 \mu \mathrm{g} \cdot 1^{-1}\right)$ were filter-sterilized and added to the autoclaved medium. Each of the isolates was spotted on the chitin medium and incubated at $28^{\circ} \mathrm{C}$ for $72 \mathrm{~h}$. A clear zone around the colony indicated chitin-solubilization by chitinase producing bacteria.

\section{Cellulase production}

M9 medium agar amended with $10 \mathrm{~g} \cdot \mathrm{l}^{-1}$ cellulose and $1.2 \mathrm{~g} \cdot \mathrm{l}^{-1}$ yeast extract was used to test for cellulase activity (Miller 1974). A clear halo after 8 days of incubation at $28^{\circ} \mathrm{C}$ was considered apositive response for cellulase production.

\section{Proteolytic activity}

Protease activities of Pseudomonas strains were determined according to the method reported by Jha et al. (2009). Skim milk agar was used and consisted of $5 \mathrm{~g} \cdot \mathrm{l}^{-1}$ pancreatic digest of casein, $2.5 \mathrm{~g} \cdot \mathrm{l}^{-1}$ yeast extract, $1.0 \mathrm{~g} \cdot 1^{-1}$ glucose, $100 \mathrm{ml} \cdot 1^{-1}$ of $7 \%$ skim milk solution and $15 \mathrm{~g} \cdot \mathrm{l}^{-1}$ agar. Bacterial cells were inoculated by the spot method and incubated for $48 \mathrm{~h}$ at $28^{\circ} \mathrm{C}$. After incubation, the plates were observed for the clear zone around the colony. A clear zone around the colony indicates protease production.

\section{Hydrogen cyanide (HCN) production}

To determine the production of HCN, bacterial isolates were streaked into King's B agar medium supplemented with glycine at $4.4 \mathrm{~g} \cdot \mathrm{l}^{-1}$. A piece of filter paper having $0.5 \%$ picric acid (yellow in color) and $2 \%$ sodium carbonate was positioned on the lid with Petri plates, then inverted, sealed with parafilm and incubated at $28^{\circ} \mathrm{C}$ for $96 \mathrm{~h}$. Discoloration of the filter paper to orange/brown after incubation indicated microbial production of hydrogen cyanide (Bakker and Schippers 1987).

\section{Statistical analysis}

Data were subjected to ANOVA at $\mathrm{p} \leq 0.01$ with interactions tested between the various factors for T. urticae mortality rates and repellent activities (Snedecor and Cocharn 1967). To determine the efficacy of Pseudomonas strains on T. urticae, mortality data were analyzed using Abbott's formula for acaricide activity (Abbott 1925), and Pascual-Villalobos and Robledo's (1998) equation for repellent activity. Resulting means were compared using Newman-Keuls test. The LC $_{50}$ values and $95 \%$ confidence limit were calculated from probit regressions using the Polo-PC software (LeOra Software 1987). The index of significance for potency estimation "g" which is used for calculation of confidence limits at three probability levels - 90, 95, and 99\%. If, at any of these levels, "g" exceeds 1.00, the values of the mean may lie outside the limits. As a safety feature, POLO-PC calculates confidence limits only when " $\mathrm{g}$ " is less than 0.5 at either the 90,95 , or $99 \%$ probability levels. The results of identification of each strain were interpreted using Apiweb $^{\circledR}$ software (Biomerieux, France).

\section{Results}

No interactions $(\mathrm{p}>0.01)$ were detected between bacterial isolates with different concentrations or time intervals, or concentrations with time intervals for T. urticae mortality rates and repellence. Therefore, data are presented only as main effects.

\section{Fluorescent Pseudomonas isolation and characterization}

The three Pseudomonas isolates evaluated (Q110B, Q036B and Q172B) had fluorescence production with diffusible yellowish-green pigment which fluoresced under ultraviolet light $(360 \mathrm{~nm})$. All strains were motile rods, testing positive for catalase and oxidase, and were Gram-negative. Q172B was positive for nitrate reduction, while Q110B and Q036B were negative (Table 1). Q110B and Q036B were positive for gelatin liquefaction, whereas Q172B was negative. All three strains were arginine deshydrogenase positive, and can use glucose as a source of carbon, but were negative for mannitol and sucrose utilization. The three strains can be grown in media ranging from $\mathrm{pH} 5$ top $\mathrm{H} 10$ and at temperatures ranging from 4 to $44^{\circ} \mathrm{C}$, except for $\mathrm{Q} 172 \mathrm{~B}$ which cannot grow at $4^{\circ} \mathrm{C}$. All will grow under saline conditions $(\mathrm{NaCl} \%)$, up to $6 \%$ for Q036B and Q110B and up to 5\% for Q172B (Table 2).

Pure cultures of each isolate were identified using API 20 NE kit (Biomerieux, France). The results were interpreted using Apiweb $^{\circledR}$ software and identified Q172B as P. putida, and Q036B and Q110B as $P$. fluorescens. These fluorescent Pseudomonas bacterial isolates were used in all subsequent work.

\section{Acaricidal activity}

All three Pseudomonas isolates provided significant amounts of mortality to T. urticae adults 24,48 and $72 \mathrm{~h}$ after treatment, although specific isolates provided higher mortality rates than others (Table 3 ). The earliest deaths occurred within $24 \mathrm{~h}$ after application. The symptoms caused by Pseudomonas isolates on T. urticae were reduction of movement and the occurrence of brown-black coloration (Aksoy et al. 2008). The most rapid T. urticae deaths ( $24 \mathrm{~h}$ after treatment) 
Table 1. Biochemical characteristics of fluorescent Pseudomonas bacterial isolates: Q172B, Q036B and Q110B

\begin{tabular}{ccccccccccccc}
\hline Pseudomonas isolate & Gram & $\mathrm{Fl}$ & $\mathrm{Ox}$ & $\mathrm{Mt}$ & $\mathrm{Ca}$ & $\mathrm{N}$ & $\mathrm{Arg}$ & $\mathrm{L}$ & $\mathrm{Gl}$ & $\mathrm{Glu}$ & Suc & Man \\
\hline Q172B & - & + & + & + & + & + & + & - & - & ox & - & - \\
Q036B & - & + & + & + & + & - & + & + & + & ox/fr* & - & - \\
Q110B & - & + & + & + & + & - & + & - & + & ox & - & - \\
\hline
\end{tabular}

$\mathrm{FI}$ - fluorescence, Ox - oxydase, Ca - catalase, Mt - motility, N - nitrate, Arg - arginine, L - leven, Gl - gelatin, Glu - glucose, Suc - sucrose, Man - mannitol, *ox - oxidation, $\mathrm{fr}$ - fermentation

Table 2. Effects of $\mathrm{pH}$, temperature and $\mathrm{NaCl}$ concentration on growth of fluorescent Pseudomonas bacterial isolates: Q172B, Q036B and Q110B

\begin{tabular}{|c|c|c|c|c|c|c|c|c|c|c|c|c|c|c|c|c|c|c|c|}
\hline \multirow[t]{2}{*}{ Pseudomonas isolate } & \multicolumn{6}{|c|}{$\mathrm{pH}$} & \multicolumn{6}{|c|}{$\begin{array}{c}\text { Temperature } \\
{\left[{ }^{\circ} \mathrm{C}\right]}\end{array}$} & \multicolumn{7}{|c|}{$\begin{array}{c}\mathrm{NaCl} \\
{[\%]}\end{array}$} \\
\hline & 3 & 5 & 7 & 9 & 10 & 12 & 4 & 12 & 20 & 26 & 36 & 44 & 1 & 2 & 3 & 4 & 5 & 6 & 8 \\
\hline Q172B & - & + & + & + & + & - & - & + & + & + & + & - & + & + & + & + & + & - & - \\
\hline Q036B & - & + & + & + & + & - & + & + & + & + & + & - & + & + & + & + & + & + & - \\
\hline Q110B & - & + & + & + & + & - & + & + & + & + & + & - & + & + & + & + & + & + & - \\
\hline
\end{tabular}

"+"- growth and "-" - inhibition. Q172B is P. putida; Q036B and Q110B are P. fluorescens

Table 3. Effects of Pseudomonas isolates Q110B, Q036B and Q172B on Tetranychus urticae adult mortality rates

\begin{tabular}{|c|c|c|c|c|}
\hline \multirow{2}{*}{ Pseudomonas isolate } & \multirow{2}{*}{$\begin{array}{l}\text { Concentration } \\
{\left[\mathrm{cfu} \cdot \mathrm{ml}^{-1}\right]}\end{array}$} & \multicolumn{3}{|c|}{ Hours after application } \\
\hline & & 24 & 48 & 72 \\
\hline \multirow{5}{*}{ Q110B } & $10^{2}$ & $7.8 \pm 5.9 \mathrm{a}$ & $31.5 \pm 22.7 \mathrm{a}$ & $53.7 \pm 29.2 \mathrm{a}$ \\
\hline & $10^{4}$ & $13.1 \pm 8.7 \mathrm{ab}$ & $38.7 \pm 10.9 \mathrm{a}$ & $67.8 \pm 21.0 \mathrm{ab}$ \\
\hline & $10^{6}$ & $23.0 \pm 12.9 \mathrm{abc}$ & $52.0 \pm 18.0 \mathrm{ab}$ & $79.0 \pm 13.9 \mathrm{bcd}$ \\
\hline & $10^{8}$ & $23.1 \pm 12.9 \mathrm{abc}$ & $55.9 \pm 14.2 \mathrm{ab}$ & $84.4 \pm 9.7 \mathrm{bcd}$ \\
\hline & $10^{10}$ & $34.6 \pm 15.4 \mathrm{~cd}$ & $64.8 \pm 22.5 b c$ & $87.7 \pm 14.1 \mathrm{bcd}$ \\
\hline \multirow{5}{*}{ Q036B } & $10^{2}$ & $16.0 \pm 12.3 \mathrm{ab}$ & $42.4 \pm 16.8 \mathrm{ab}$ & $69.2 \pm 25.1 \mathrm{ab}$ \\
\hline & $10^{4}$ & $27.5 \pm 17.8 \mathrm{bcd}$ & $80.1 \pm 27.8 \mathrm{~cd}$ & $94.4 \pm 12.7 \mathrm{~cd}$ \\
\hline & $10^{6}$ & $39.9 \pm 13.3 c$ & $85.6 \pm 17.3 d$ & $96.6 \pm 7.8 \mathrm{~cd}$ \\
\hline & $10^{8}$ & $41.2 \pm 16.2 c$ & $86.7 \pm 14.0 \mathrm{~d}$ & $97.6 \pm 5.4 \mathrm{~d}$ \\
\hline & $10^{10}$ & $61.9 \pm 16.2 \mathrm{e}$ & $88.1 \pm 18.7 d$ & $98.8 \pm 4.0 \mathrm{~d}$ \\
\hline \multirow{5}{*}{ Q172B } & $10^{2}$ & $13.5 \pm 11.9 \mathrm{ab}$ & $30.8 \pm 19.9 \mathrm{a}$ & $54.5 \pm 19.0 \mathrm{a}$ \\
\hline & $10^{4}$ & $20.9 \pm 13.2 \mathrm{abc}$ & $34.4 \pm 18.2 \mathrm{a}$ & $75.1 \pm 21.4 \mathrm{bc}$ \\
\hline & $10^{6}$ & $21.8 \pm 8.6 a b c$ & $37.7 \pm 23.2 \mathrm{a}$ & $86.8 \pm 13.5 \mathrm{bcd}$ \\
\hline & $10^{8}$ & $29.9 \pm 14.9 \mathrm{bcd}$ & $45.5 \pm 21.7 \mathrm{ab}$ & $88.0 \pm 14.4 \mathrm{bcd}$ \\
\hline & $10^{10}$ & $26.4 \pm 10.4 \mathrm{bcd}$ & $47.9 \pm 17.6 \mathrm{ab}$ & $89.0 \pm 11.4 \mathrm{bcd}$ \\
\hline
\end{tabular}

By column, the rates followed by the same letters are not statistically different at $p \leq 0.01$ according to the Newman-Keuls test

were obtained by Q036B which had a mortality rate of about $62 \%$ at $10^{10} \mathrm{cfu} \cdot \mathrm{ml}^{-1}$ concentration, while Q172B and Q110B had approximately 26 and 35\% mortality rates, respectively. At the highest concentrations, T. urticae mortality rates exceeded $50 \% 48 \mathrm{~h}$ after application, except for Q172B; and, more than $80 \%$ mortality was already achieved by Q036B at this time. The highest mortality rate (99\%) was observed $72 \mathrm{~h}$ after application of Q036B. For the other two strains (Q172B and Q110B), the mortality rates were similar $72 \mathrm{~h}$ after application, and ranged from 54 to $89 \%$. This was further confirmed by probit analysis indicating that the Pseudomonas isolate Q036B was the most toxic, and had an $\mathrm{LD}_{50}$ of $0.585 \mathrm{cfu} \cdot \mathrm{ml}^{-1}$ compared to 90.846 and $169.585 \mathrm{cfu} \cdot \mathrm{ml}^{-1}$ for Q172B and Q110B, respectively (Table 4). 
Table 4. Log-dose probit mortality data for Tetranychus urticae adults tested with three Pseudomonas isolates

\begin{tabular}{ccccccc}
\hline $\begin{array}{c}\text { Pseudomonas } \\
\text { isolate }\end{array}$ & $\begin{array}{c}\mathrm{LC}_{50} \\
{\left[\mathrm{cfu} \cdot \mathrm{ml}^{-1}\right]}\end{array}$ & Fiducial limits & Slope $\pm \mathrm{SE}$ & $\mathrm{g}$ & $\log (\mathrm{L})$ & $\mathrm{N}$ \\
\hline Q036B & 0.598 & 0.0 to 22.110 & $0.252 \pm 0.037$ & 0.162 & -269.7 & 789 \\
Q172B & 90.846 & 0.195 to $2,530.947$ & $0.192 \pm 0.026$ & 0.139 & -447.5 & 838 \\
Q110B & 169.585 & 0.007 to $12,918.491$ & $0.144 \pm 0.026$ & 0.242 & -479.0 & 791 \\
\hline
\end{tabular}

Log (L) - logarithm of the maximum value of the likelihood function; $\mathrm{N}$ - number of test subjects (individuals); $\mathrm{g}$ - index of significance for potency estimation

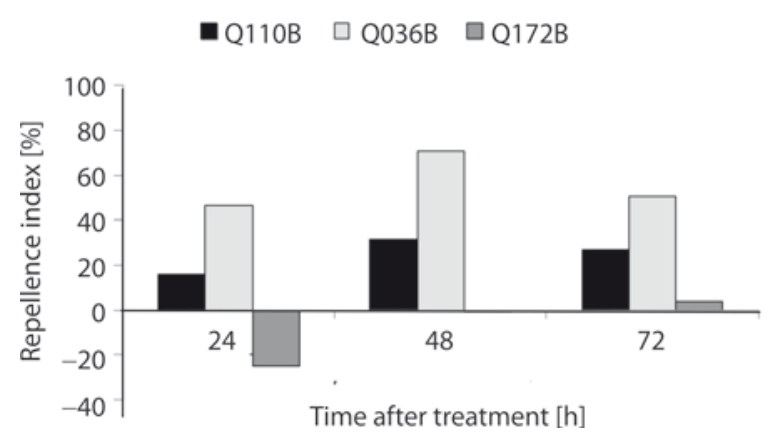

Fig. 2. Repulsive effect of Pseudomonas Q110B, Q036B and Q172B isolates on Tetranychus urticae adults. The repellence index (\%) followed by the same letters do not differ at $p \leq 0.01$ according to the Newman-Keuls test

\section{Repellent activity}

The three Pseudomonas isolates evaluated repelled T. urticae adults at 24, 48 and 72 h (Fig. 2). However, all three Pseudomonas isolates had a repellent effect only $72 \mathrm{~h}$ after application. The repellence index (RI) of the three isolates tested at $10^{10} \mathrm{cfu} \cdot \mathrm{ml}^{-1}$ are shown in Figure 2 at 24, 48 and $72 \mathrm{~h}$ after application. At 72 h, both Pseudomonas Q110B and Q172B isolates had a low repellent effect on T. urticae adults with RI ranging from 4 to $27 \%$, while Pseudomonas isolate Q036B provided the highest repellent effect of 50\%.

\section{Acaricidal mechanism}

To elucidate the potential mechanism of action that could be involved in T. urticae adult mortality and repellency, the Pseudomonas isolates were characterized biochemically in vitro for chitinase, cellulase, and protease activity, and hydrogen cyanine production (Table 5). The chitinase plate tests of both Pseudomonas strains Q036B and Q172B had a clear halo surrounding the colony which confirmed their ability to induce chitin degradation; however, no chitinase activity was recorded for Q110B. For cellulase and protease activity, all Pseudomonas isolates tested positive, since a clear halo surrounded the colony in Petri plate observations for these enzymes. All fluorescent Pseudomonas isolates evaluated produced hydrogen cyanide, as indicated by discoloration of filter paper when incubated with picric acid $(0.5 \%)$ and sodium carbonate $(2 \%)$.

\section{Discussion}

The results of this study indicate that fluorescent Pseudomonas, especially P. fluorescens and P. putida have a high biological control efficacy against the phytophagous mite T. urticae. The genus Pseudomonas is known to have biocontrol potential for some pest species such as leaf folder insect, Cnaphalocrocis medinalis (Commare et al. 2002). Moreover, Aksoy et al. (2008) indicated that P. putida had a high efficacy and caused significant amounts of mortality to two-spotted spider mites. Pseudomonas fluorescens has also been shown to control the red spider mite (Oligonychus coffeae) (Roobakkumar et al. 2011). Pseudomonas aeruginosa has also been reported to control T. urticae (Poinar and Poinar 1998). Our study provides further evidence that $P$. putida and $P$. fluorescens will cause increased mortality of the adult of two-spotted mite, T. urticae, and have potential as biological control agents for this pest.

Table 5. In vitro chitinase, cellulase, protease activity, and hydrogen cyanide (HCN) production by fluorescent Pseudomonas isolates

\begin{tabular}{ccccc}
\hline Pseudomonas isolate & Chitinase activity* & Protease activity & Cellulase activity & HCN production \\
\hline Q036B & + & + & + & + \\
Q172B & + & + & + & + \\
Q110B & - & + & + & + \\
\hline
\end{tabular}

*chitinase, protease and cellulase activity were detected by clear halo surrounding the colony; and, hydrogen cyanide detected by discoloration of filter paper when incubated with reagent 
Fluorescent Pseudomonas bacteria act by several mechanisms for insect and mite pests, although the ability to degrade chitin is often considered the primary factor involved. Chitinolytic organisms, such as Pseudomonas sp. isolated from the rhizosphere, have been shown to have potential as biological control agents (Commare et al. 2002). Vodovar et al. (2006) reported that $P$. entomophila provides mortality to Drosophila melanogaster due to strong hemolytic activity, which involves proteins, such as lipases, chitinases and/or hydrolases. Furthermore, several researchers have indicated that bacterial chitinases were effective in providing control of insects and mites by hydrolyzing their chitinous exoskeleton (Broadway et al. 1998).Wilson et al. (2002) reported that bacterial hemolysins are exotoxins that attack blood cell membranes and cause cell rupture. This may also be involved in the pathogenicity of Pseudomonas strains on $T$. urticae, especially given the rapid mortality caused by Q036B. Additionally, Vodovar et al. (2006) indicated that pathogenic bacteria rely on a variety of cell surface-associated virulence factors that allow adhesion to the host surface to promote effective colonization. If applicable to Pseudomonas strains, this adhesion could enhance the incursion of proteases, chitinases, lipases and hydrolases through the cuticle, stigmas and body orifices of T. urticae, which can lead to the rapid death of the mite. Furthermore, the repellent effect of Pseudomonas strains can possibly be explained by the production of secondary metabolites, including volatile metabolites which kept mites from treated leaves in our study (Raaijmakers et al. 2002).

Biopesticides are key components of integrated pest management programs, and are often a way to reduce the amount of synthetic chemical products being used to control plant pests and diseases. Many horticultural crop growers throughout the world are now exploring their potential applicability due to ongoing pesticide restrictions. Results from our study further suggest that bacterial epiphytes and rhizospherics, some of which are of interest for use in the biological control of plant pathogens and pests, could also be examined for their potential use in insect pest management (Kupferschmied et al. 2013). This study indicated that although all three fluorescent Pseudomonas isolates provided significant death and repellence to T. urticae. Pseudomonas fluorescens isolate Q036B was the most promising candidate for biological control of T. urticae, and has potential to contribute to an integrated pest management program to control this important pest. Indeed, the fruits produced will be qualified as safe for both the consumer and the environment. This study will be a preliminary step for future work that will help policy decision makers support agroecological potential which will meet the needs of industries and maintain ecological balance.
Future research is planned to evaluate the impact of these Pseudomonas isolates under greenhouse conditions and to assess toxic and repellent effects to control other key pests of tomato (russet mite, whiteflies, leaf miners, thrips and aphids). On the other hand, the plant growth promoting rhizobacteria (PGPR) impact will be the most important study to ascertain the uses of these isolates as an alternative application to chemicals (fertilizers).

In addition, we propose molecular studies of these isolates. These may proceed from ascertaining key qualities of bacterial genomes and work towards sequence studies leading towards quantitative and qualitative measurement of the factors involved (Kearsey and Pooni 1998).

\section{Acknowledgements}

We are very grateful to the SAOAS company's natural enemy production unit for their technical assistance in mass rearing of two spotted mite T. urticae.

\section{References}

Abbott W. 1925. A method of computing the effectiveness of an insecticide. Journal of Economic Entomology 18 (2): 265-267. DOI: https://doi.org/10.1093/jee/18.2.265a

Aksoy H.M., Ozman-Sullivan S.K., Ocal H., Celik N., Sullivan G.T. 2008. The effects of Pseudomonas putida biotype B on Tetranychus urticae (Acari: Tetranychidae). Experimental and Applied Acarology 46 (1-4): 223-230. DOI: https://doi. org/10.1007/s10493-008-9155-9

Arzanlou M., Mousavi S., Bakhshi M., Khakvar R., Bandehagh A. 2016. Inhibitory effects of antagonistic bacteria inhabiting the rhizosphere of the sugarbeet plants, on Cercospora beticola Sacc., the causal agent of Cercospora leaf spot disease on sugar beet. Journal of Plant Protection Research 56 (1): 6-14. DOI: https://doi.org/10.1515/jppr-2016-0002

Attia S., Grissa K.L., Mailleux A.C., Lognay G., Heuskin S., Mayoufi S., Hance T. 2012. Effective concentrations of garlic distillate (Allium sativum) for the control of Tetranychus urticae (Tetranychidae). Journal of Applied Entomology 136 (4): 302-312. DOI: https://doi.org/10.1111/j.1439-0418 .2011.01640.x

Bakker A.W., Schippers B. 1987. Microbial cyanide production in the rhizosphere in relation to potato yield reduction and Pseudomonas spp. mediated plant growth stimulation. Soil Biology and Biochemistry 19 (4): 451-457. DOI: https:// doi.org/10.1016/0038-0717(87)90037-x

Bossis E., Lemanceau P., Latour X., Gardan L. 2000. The taxonomy of Pseudomonas fluorescens and Pseudomonas puti$d a$ : current status and need for revision. Agronomie 20 (1): 51-63. DOI: https://doi.org/10.1051/agro:2000112

Bouharroud R., Hanafi A., Serghini M.A. 2007. Pyrethroids and endosulfan resistance of Bemisia tabaci in the tomato greenhouses of the Souss valley of Morocco. Acta Horticulturae 747: 409-413. DOI: https://doi.org/10.17660/ actahortic.2007.747.51

Broadway R.M., Gongora C., Kain W.C., Sanderson J.P., Monroy J.A., Bennett K., Warner J.B., Hoffmann M.P. 1998. Novel chitinolytic enzymes with biological activity against herbivorous insects. Journal of Chemical Ecology 24 (6): 985-998. DOI: https://doi.org/10.1023/A:1022346301626 
Carey J., Bradley J. 1982. Developmental rates, vital schedules, sex ratios and life tables for Tetranychus urticae, T. turkestani and T. pacificus (Acarina: Tetranychidae) on cotton. Acarologia 23 (4): 333-345.

Cattelan A., Hartel P., Fuhrmann J. 1999. Screening for plant growth-promoting rhizobacteria to promote early soybean growth. Soil Science Society of America Journal 63 (6): 1670-1680. DOI: https://doi.org/10.2136/sssaj1999.6361670x

Commare R.R., Nandakumar R., Kandan A., Suresh S., Bharathi M., Raguchander T., Samiyappan R. 2002. Pseudomonas fluorescens based bio-formulation for the management of sheath blight disease and leaffolder insect in rice. Crop Protection 21 (8): 671-677. DOI: https://doi.org/10.1016/ s0261-2194(02)00020-0

Falkow S. 1958. Activity of lysine decarboxylase as an aid in the identification of Salmonellae and Shigellae. American Journal of Clinical Pathology 29 (6): 598-600.

Fiedler Ż. 2012. Interaction between beneficial organisms in control of spider mite Tetranychus urticae (Koch.). Journal of Plant Protection Research 52 (2): 226-229. DOI: https:// doi.org/10.2478/v10045-012-0035-2

Hamza A., Mohamed A., Derbalah A. 2016. Unconventional alternatives for control of tomato root rot caused by Rhizoctonia solani under greenhouse conditions. Journal of Plant Protection Research 56 (3): 298-305. DOI: https://doi. org/10.1515/jppr-2016-0046

Hugh R., Leifson E. 1953. The taxonomic significance of fermentative versus oxidative metabolism of carbohydrates by various gram negative bacteria. Journal of Bacteriology 66 (1): 24 .

Jha B.K., Pragash M.G., Cletus J., Raman G., Sakthivel N. 2009. Simultaneous phosphate solubilization potential and antifungal activity of new fluorescent pseudomonad strains, Pseudomonas aeruginosa, $P$. plecoglossicida and P. mosselii. World Journal of Microbiology and Biotechnology 25 (4): 573-581. DOI: https://doi.org/10.1007/s11274-008-9925-x

Kearsey M.J., Pooni H.S. 1998. The Genetical Analysis of Quantitative Traits. Stanley Thornes (Publishers) Ltd., Cheltenham, UK, $381 \mathrm{pp}$.

King E.O., Ward M.K., Raney D.E. 1954. Two simple media for the demonstration of pyocyanin and fluorescin. Journal of Laboratory and Clinical Medicine 44: 301-307.

Kupferschmied P., Maurhofer M., Keel C. 2013. Promise for plant pest control: root-associated pseudomonads with insecticidal activities. Frontiers in Plant Science 4: 287. DOI: https://doi.org/10.3389/fpls.2013.00287

LeOra Software. 1987. POLO-PC. A user's guide to Probit or Logit analysis. LeOra Software, Berkeley, CA.

Miller J.H. 1974. Experiments in Molecular Genetics. 2nd ed. Cold Spring Harbor Laboratory Press, NY, 466 pp.

Neethu K.B., Priji P., Unni K.N., Sajith S., Sreedevi S., Ramani N., Anitha K., Rosana B., Girish MB., Benjamin S. 2015. New Bacillus thuringiensis strain isolated from the gut of Malabari goat is effective against Tetranychus macfarlanei. Journal of Applied Entomology 140 (3): 187-198. DOI: https://doi.org/10.1111/jen.12235

Park Y.L., Lee J.H. 2002. Leaf cell and tissue damage of cucumber caused by two spotted spider mite (Acari: Tetranychi- dae). Journal of Economic Entomology 95 (5): 952-957. DOI: https://doi.org/10.1093/jee/95.5.952

Pascual-Villalobos M., Robledo A. 1998. Screening for anti-insect activity in Mediterranean plants. Industrial Crops and Products 8 (3): 183-194. DOI: https://doi.org/10.1016/ s0926-6690(98)00002-8

Poinar Jr. G., Poinar R. 1998. Parasites and pathogens of mites. Annual Review of Entomology 43(1): 449-469. DOI: https://doi.org/10.1146/annurev.ento.43.1.449

Raaijmakers J.M., Vlami M., De Souza J.T. 2002. Antibiotic production by bacterial biocontrol agents. Antonie Van Leeuwenhoek Journal of Microbiology 81 (1-4): 537-547.

Rathore A.S., Gupta R.D. 2015. Chitinases from bacteria to human: properties, applications, and future perspectives. Enzyme Research 2015: 1-8. DOI: https://doi. org/10.1155/2015/791907

Roobakkumar A., Babu A., Kumar D.V., Sarkar S. 2011. Pseudomonas fluorescens as an efficient entomopathogen against Oligonychus coffeae (Nietner) (Acari: Tetranychidae) infesting tea. Journal of Entomology and Nematology 3 (5): 73-77.

Ruiu L. 2015. Insect pathogenic bacteria in integrated pest management. Insects 6 (2): 352-367. DOI: https://doi. org/10.3390/insects6020352

Sarma B., Acharya C., Joshi S.R. 2012. Plant browth promoting and metal bioadsorption activity of metal tolerant Pseudomonas aeruginosa isolate characterized from uranium ore deposit. Proceedings of the National Academy of Sciences, India Section B: Biological Sciences 84 (1): 157-164. DOI: https://doi.org/10.1007/s40011-012$-0136-8$

Snedecor G.W., Cochran W.C. 1967. Statistical Methods. Oxford and IBH publishing co. New Delhi, 593 pp.

Van Leeuwen T., Vontas J., Tsagkarakou A., Dermauw W., Tirry L. 2010. Acaricide resistance mechanisms in the twospotted spider mite Tetranychus urticae and other important Acari: a review. Insect Biochemistry and Molecular Biology 40 (8): 563-572. DOI: https://doi.org/10.1016/j. ibmb.2010.05.008

Van Lenteren J.C. 2012. The state of commercial augmentative biological control: plenty of natural enemies, but a frustrating lack of uptake. BioControl 57 (1): 1-20. DOI: https://doi.org/10.1007/s10526-011-9395-1

Vodovar N., Vallenet D., Cruveiller S., Rouy Z., Barbe V., Acosta C., Cattolico L., Jubin C., Lajus A., Segurens B. 2006. Complete genome sequence of the entomopathogenic and metabolically versatile soil bacterium Pseudomonas entomophila. Nature Biotechnology 24 (6): 673-679. DOI: https://doi.org/10.1038/nbt1212

Wilson M., McNab R., Henderson B. 2002. Bacterial Disease Mechanisms: an Introduction to Cellular Microbiology. Cambridge University Press, UK, 656 pp.

Zhang C.R., Zhang S.Z., Xia J., Li F.F., Xia W.Q., Liu S.S., Wang X.W. 2014. The immune strategy and stress response of the Mediterranean species of the Bemisia tabaci complex to an orally delivered bacterial pathogen. PloS One 9 (4): e94477. DOI: https://doi.org/10.1371/journal.pone.0094477 